\title{
IMPLEMENTASI PANCASILA SEBAGAI PARADIGMA PEMBANGUNAN EKONOMI POLITIK, SOSIAL DAN BUDAYA YANG BERWAWASAN KEMARITIMAN PADA MASA PANDEMI COVID-19
}

\author{
Tugino $^{1^{*}}$, Harini ${ }^{2}$ \\ ${ }^{1}$ Program Studi Teknik Permesinan Kapal Fakultas Kemaritiman UNISVET \\ Jl.Pawiyatan Luhur IV no.17 Bendan Dhuwur Semarang \\ ${ }^{2}$ Program Studi Teknik KelistrikanKapal Fakultas Kemaritiman UNISVET \\ Jl.Pawiyatan Luhur IV no.17 Bendan Dhuwur Semarang \\ *Email: tuginoutomo8@gmail.com
}

\begin{abstract}
Abstrak
Nilai - nilai Pancasila sebagai paradigma pembanguan ekonomi dalam menghadapi wabah Covid-19 perlu membutuhkan kebersamaan persatuan dan kesatuan bangsa sehingga tidak terpecah belah dalam menghadapi upaya penanganan Covid-19. Oleh karena itu, masih relevan dengan konteks berkaitan pandemi mulai gotong- royong yang telah dibangun dan yang telah digelorakan para pendiri negara yang saat ini sangat dirasakan di tengah-tengah masyarakat. Pancasila sebagai paradigma pembangunan ekonomi pada masa pandemi Covid-19 berbijak pada nilai - nilai moral daripada Pancasila secara khusus sistim ekonomi harus mendasarkan pada moralitas sesuai dengan sila pertama mengajarkan nilai keimanan dan keiklasan dalam menghadapi wabah Covid-19 tetap membangun dan memulihkan ekonomi pada saat pandemi untuk kesejahterakan rakyat berdasarkan kekeluargaan. Berdasarkan sila ke dua Pancasila pembangunan sosial budaya di kembangkan atas dasar penghargaan terhadap nilai sosial budaya yang beragam di seluruh Indonesia menuju pada tercapainya rasa persatuan sebagai bangsa sehingga empati kemanusiaan haruslah melahirkan persatuan gotong royong untuk menyelesaikan masalah, kebersamaan ini yang akan mempercepat penanganan pandemic Covid-19, saling membantu berbagi dan berkolaborasi tanpa melihat Ras, suku, agama, adalah tidak luput dari peran sila ke tiga Pancasila
\end{abstract}

Kata kunci: relevansi nilai pancasila pada masa pandemi

\section{PENDAHULUAN}

Kita dapat melihat perkembangan di Indonesia yang berkelanjutan dengan penyebaran wabah virus corona Covid-19 Irfan Kamil (2020) bahkan sampai tingkat Dunia yang mana belum dipastikan kapan akan ujung berakhirnya yang sampai meluluh lantahkan dari sendi - sendi kehidupan Ekonomi, Sosial Budaya Politik dan Hankam bahkan krisis kesehatan maupun psikologis dengan kondisi ini pemerintah Indonesia dalam memberikan kebijakan aturan yang dinamakan pembatasan sosial (social distancing), dan dalam menghadapi wabah pandemi ini tantangan yang dihadapi tidak mudah kentara berdampak pada sektor ekonomi, politik sosial budaya dan pertahanan dan keamanan.

\section{LANDASAN TEORI}

Budiono (2012) menyebutkan Sesuai dengan paradigma Pancasila dalam pembangunan ekonomi, sistim ekonomi harus mendasarkan pada moralitas ketuhanan, dan kemanusiaan, hal itu bertujuan untuk mensejahterakan,Oleh sebab itu, Nunuk (2020) dalam makalahnya Pancasila sebagai dasar idiologi negara Indonesia memiliki nilai - nilai yang menjadikan kekuatan bangsa Indonesia sebagai bangsa antara lain rasa persatuan gotong royong meningkatkan solidaritas yang dibutuhkan dalam menghadapi wabah pademi Covid-19 yang samapai saat ini wabahnya mendunia,oleh karena itu massa pandemi Covid-19 ini adalah momentum untuk menekankan bagaimana pentingnya nilai - nilai Pancasila teruji terhadap satu kesatuan bangsa dan nilai nilai tersebut adalah merupakan idiologi dasar dari 
Pancasila dan Pancasila akan teruji kesaktiannya disaat kita bersatu padu dalam kebersamaan tidak gentar akan menghadapi wabah Pandemi Covid-19 ini dan dibutuhkan solidaritas yang kuat di mulai dari tingkat pusat sampai tingkat lapisan bawah sehingga Pancasila sebagai sistim nilai yang dijadikan kerangka landasan dan sekaligus kerangka untuk mencapai tujuan agar segera berakhir dengan wabah pademi ini.Dalam rangka pembangunan manusia seutuhnya dan membangun masyarakat warga (civil society) Indonesia seluruhnya maka nilai - nilai Pancasila semakin relevan dengan situasi dan kondisi saat ini dimana bangsa Indonesia sedang menghadapi pandemi Covid-19 yang berdampak pada baik sektor kesehatan maupun pada sektor ekonomi, politik,sosial budaya dan pertahanan keamanan,sehingga nilai - nilai dasar Pancasila itu dikembangkan untuk menjawab tantangan yang menjadi hakekat manusia Pancasila Fukuyama dalam Astrid (2000)

Hakekat manusia adalah manusia yang menjadi humanis dan yang menjadikan kodrat manusia yang memiliki ciri - ciri antara lain ;

1. Sifat kodrat manusia sebagai individu sekaligus makluk sosial yang mestinya harus terjaga dalam masa pandemi ini .

2. Kedudukan kodrat manusia sebagai makluk pribadi dan makluk Tuhan Yang Maha Esa senantiasa bertaqwa dan berdoa dalam mensikapi wabah pandemi Covid-19 segera berlalu.

3. Susunan kodrat manusia yang terdiri atas jiwa dan raga yang harus terlindungi dalam masa pandemi ini.

Berdasarkan ketiga ciri tersebut diatas pembangunan pada masa pandemi ini diarahkan sebagai upaya meningkatkan harkat dan martabat manusia yang meliputi aspek jiwa , raga, pribadi social dan aspek kesatuan pembangunan nasional sebagai upaya peningkatan manusia secara berkualitas kehidupan dalam menghadapi pandemiyang belum kunjung reda kata. Heri Hardiawanto dkk (2019) hakekat kedudukan Pancasila sebagai paradigma pembangunan nasional mengandung konsekwensi menjelaskan filosofis bahwa dalam setiap pelaksanaan pembangunan nasional didasarkan atas nilai - nilai yang terkandung dalam Pancasila Elly Setiadi (2005) bahwa dengan Pancasila, menempatkan Pancasila sebagai paradigma pembangunan nasional harus mencerminkan pendalaman semua sila Pancasila sebagai satu kesatuan yang utuh.

\section{METODE}

Penulisan ini menggunakan methode empiris atau non doktrinal, jenis data yang digunakan dalam penelitian ini adalah data primer dan sekunder, dalam hal ini penulis telah melakukan pengkajian melalui bahan pustaka atau data sekunder yang terdiri dari bahan primer dan bahan sekunder.

\section{HASIL DAN PEMBAHASAN

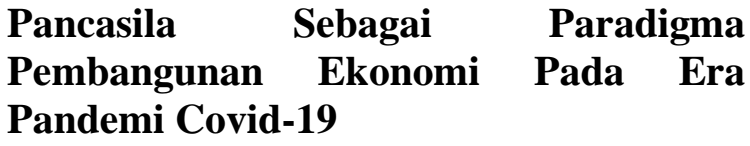

Rohani (2019) dijelaskan bahwa sumber nilai sesuai dengan paradigma Pancasila dalam pembangunan ekonomi maka soliditas dan pembangunan ekonomi berpijak pada nilai moral daripada Pancasila secara khusus sistim ekonomi harus mendasar pada moralitas sesuai dengan sila I (pertama) Pancasila yang mengajarkan nilai keimanan kepada taqdir Tuhan bahwa manusia hanya merencana seperti membangun ekonomi akan berhasil tetapi hasil akhir berada di tangan Tuhan Yang Maha Kuasa ,seperti wabah Covid-19 adalah bagian dari ujian dalam kehidupan yang harus semakin menjadikan kita tambah kekuatan di luar dugaan mereka,sehingga relegiusitas harus menyadarkan kita semakin kuat dimasa pandemi ini.

Sistim ekonomi yang mendasarkan pada moralitas dan humanistis akan menghasilakan sistim ekonomi yang berperikemanusiaan yaitu sistim ekonomi yang menghadapi hakekat manusia baik selaku makluk individu social sekaligus makluk pribadi makluk Tuhan lebih meningkatkan keyakinan bahwa kita bisa oleh karena itu sistim ekonomi yang harus 
dikembangkan menjadi sistim dalam pembangunan ekonomi yang mempunyai tujuan pada saat pandemi Covid-19 ini untuk kesejahteraan rakyat secara keseluruhan harus mendasarkan pada Pancasila yaitu berazaskan pada nilai kerakyatan dan kekeluargaan .

Secara umum sistim ekonomi di Indonesia juga tidak dapat dipisahkan dari nilai - nilai moral kemanusiaan pada masa pandemi Covid-19 pembangunan ekonomi harus mampu menyadarkan diri dari bentuk bentuk moralitas persaingan bebas dan bahkan menambah penderitaan kesengsaraan pada masyarakat.sehingga perlunya Pancasila sebagai paradigma pembangunan ekonomi haruslah mengacu pada esensi pada sila ke empat (Kerakyatan yang dipimpin oleh hikmat kebijaksanaan dalam permusyawratan perwakilan) artinya bahwa kebijakan pemimpin dan elit pemerintah dibutuhkan untuk menghasilkan kebijakan negara yang benar - benar berorientasi pada kepentingan dan keberpihakan kepada rakyat dalam menangani pandemi Covid-19 ini .

Dan dampaknya pada keberlangsungan tidak ada yang boleh mengambil keuntungan atau hasrat untuk penyalahgunaan kekuasaan serta otoritas ditanggung kesulitan rakyat dengan demikian ekonomi kerakyatan politik atau kebijakan ekonomi harus untuk sebesar - besarnya kemakmuran atau kesejahteraan rakyat yang harus mampu mewujudkan perekonomian Nasional yang lebih berkeadilan bagi seluruh warga masyarakat (civilsosiety), sehingga pada ekonomi kerakyatan ini lebih memberikan kesempatan ,dan dukungan untuk pengembangan ekonomi rakyat mencakup koperasi, UMKM (Usaha Kecil dan Usaha Menengah) sebagai pilar utama Pembangunan Ekonomi Nasional .

\section{Implementasi Pancasila Sebagai Paradigma Pembangunan Sosial Budaya Pada Masa Pandemi Covid-19}

Karakteristik sila kedua Pancasila (Kemanusiaan yang adil dan beradab) disaat ini pandemi Covid-19 empati dan tanggungjawab kemanusiaan benar - benar di uji membentuk kesadaran bahwa kita tidak hidup sendiri dan berkewajiban untuk saling menjaga agar wabah Covid-19 tidak menyebar , disiplin protokol kesehatan menjadi tanggungjawab kolektif kolegial oleh karena itu Pancasila pada hakekatnya bersifat pluralistik karena Pancasila bertolak dari hakekat dan kedudukan kodrat manusia,oleh karena itu pembangunan sosial budaya harus mampu membangun meningkatkan harkat martabat dan kedudukan manusia yaitu menjadi manusia yang berbudaya dan beradab dalam menyikapi musibah pandemic Covid-19 ini dan sebagai manusia tidak cukup sebagai manusia secara fisik tetapi harus mampu meningkatkan derajad kemanusiaan dalam mensikapi kenyataan dalam wabah pandemi ini

Dengan demikian pembangunan sosial budaya pada masa pandemi Covid-19 tidak menciptakan kesenjangan, kecemburuan, diskriminasi dan tertib dalam keadilan social, paradigma baru dalam pandemi ini pembangun berkelanjutan yang dalam perencanaannya perlu diselenggarakan dengan menghormati hak sosial budaya yang terlibat untuk mengatur kehidupan berbangsa secara asasi individu secara berimbang, dalam sila kedua,paradigma ini dan cenderung dapat mengatasi sistim persaudaraan yang cenderung sosiopluralistik dan yang mengabaikan kemajemukan masyarakat dan keanekaragaman kebudayaan Indonesia.

Dengan demikian pada era pandemi Covid19 tidak akan menyerah pada ke individu daerah tetapi justru akan memadukan pembangunan daerah, dengan pembanguan nasional sehingga akan mengatur keseimbangan dan pemerataan dalam rangka memperkuat persatatuan dan kesatuan bangsa yang sanggup menegakkan kedaulatan dan keutuhan wilayah NKRI sila ketiga dalam mengurangi, memutus mata rantai masa pandemi sekarang ini.bila dicermati nilai - nilai Pancasila sebagai Puncak dan kerangka acuan bersama diantaranya sila ( I) Pertama perwujudanya 
tidak satupun pada masa pandemi dalam suku bangsa ataupun golongan sosial dan komunitas setempat yang tidak mengenal kepercayaan kepercayaan terhadap Tuhan Yang Maha Esa.

Pada sila kedua merupakan nilai budaya yang dijunjung tinggi oleh segenap warga negara Indonesia dalam menangani pandemi Covid-19 tanpa membedakan asal - usul suku bangsa kedudukan maupun golongannya. Sila ketiga mencerminkan nilai budaya yang menjadi kebulatan tekad memerangi pandemi dalam masyarakat majemuk untuk mempersatukan diri sebagai satu bangsa yang berdaulat sedangkan sila keempat merupakan nilai budaya untuk mencapai kesepakatan melalui musyawarah dan sila ini sangat relevan untuk menjadikan nilai - nilai budaya yang mendahulukan kepentingan keragaman dalam situasi dalam masa pandemi Covid-19, dilanjut pada sila ke lima betapa nilai - nilai keadilan sosial itu menjadi landasan yang membangkitkan semangat perjuangan bangsa Indonesia dalam melawan pandemi Covid-19 dan agar terhindar dari wabah yang melanda negara tercinta ini.

\section{Implementasi Pancasila Sebagai Paradigma Pembangunan Politik Manusia Indonesia Dalam Masa Pandemi Covid-19.}

Dalam sistim politik Indonesia yang sesuai Pancasila sebagai paradigma yaitu sistim politik Indonesia harus dikembangkan atas dasar azas kerakyatan prilaku politik baik dari warga negara maupun penyelenggara negara dikembangkan atas dasar moral tersebut sehingga menghasilkan prilaku politik yang santun dan bermoral. Esensi sila keempat menjadikan dibutuhkan kebijaksanaan pemimpin dan elit politik dibutuhkan untuk menghasilkan kebijakan negara yang benar - benar berorientasi pada kepentingan rakyat dalam menangani pandemi Covid-19 dan dampaknya pada keberlangsungan perikehidupan, sehingga harapan tidak ada penyalahgunaan wewenang dan orientasinya pada sila ke lima Pancasila yaitu mewujudkan kesejahteraan yang harus menjadi penggerak dari seluruh komponen negara atau elit (Nunuk, 2020).

Namun kita tidak harus mengandalkan etika politik dalam penanganan krisis ,namun diantara krisis kesehatan oleh karena setidaknya kita harus mengupayakan ada 3 hal:

Pertama; masyarakat harus inisiatif perlindungan kesehatan masyarakat secara mandiri dengan semanagat gotong- royong dalam pencegahan penyebaran Covid-19 ini harus bahu membahu membangun jejaring pengaman sosial berbasis lokal.

Kedua; dalam menangani Covid-19 masyarakat harus berusaha dan memberi apresiasi yang baik terhadap kebijakan yang di sampaikan pemerintah melalui gugus Covid-19 pusat sampai daerah atau steak holder.

Ketiga; Rakyat dan masyarakat harus mengkondisikan diri dengan kokoh supaya kepentingan publik agar lebih tercerminkan di dalam negara, saat pandemi berlangsung sampai pandemi ini berakhir.

\section{Implementasi Pancasila Sebagai Paradigma Pembangunan Pertahanan Keamanan Manusia Indonesia Dalam Masa Pandemi Covid-19.}

Salah satu tujuan pembangunan Indonesia adalah melindungi segenap bangsa Indonesia dan seluruh tumpah darah, karena hal ini mengandung makna bahwa tugas dan tanggung jawab tidak hanya oleh penyelenggara negara saja, tetapi rakyat Indonesia secara keseluruhan di dalam wabah pandemi Covid-19, selanjutnya kita harus sama - sma menjaga kesehatan kita dalam mempertahankan hidup kita ini melalui sistim pertahanan yang bersifat semesta melibatkan seluruh warga negara atau manusia dan sumber daya manusia lainnya serta serta dipersiapkan secara total terpadu terarah dan berlanjut untuk menegakkan keutuhan keselamatan segenap bangsa daripada ancaman tersebut, artinya ancaman menghadapi wabah pandemi Covid-19 yang sampai sekarang manjadi perhatian kita secara serius maka pertahanan 
dan keamanan semesta bisa melibatkan segala komponen yang ada. (Agus wijaya 2001)

\section{KESIMPULAN}

Nilai - nilai Pancasila sebagai paradigma pembanguan ekonomi dalam menghadapi wabah Covid-19 perlu membutuhkan kebersamaan persatuan dan kesatuan bangsa sehingga tidak terpecah belah dalam menghadapi upaya penanganan Covid-19, oleh karena itu masih relevansinya dengan konteks berkaitan pandemi ini yang mulai gotong- royong yang telah dibangun dan yang telah digelorakan para pendiri negara yang saat ini sangat dirasakan pada tengah tengah masyarakat.Pancasila sebagai paradigma pembangunan ekonomi pada masa pandemi Covid-19 berbijak pada nilai - nilai moral daripada Pancasila secara khusus sistim ekonomi harus mendasarkan pada moralitas sesuai dengan sila pertama mengajarkan nilai keimanan dan keihklasan dalam menghadapi wabah Covid-19 tetap membangun dan memulihkan ekonomi pada saat pandemi untuk kesejahterakan rakyat berdasarkan kekeluargaan.

Implementasi Pancasila sebagai paradigma pembanguan sosial budaya pada masa Pandemi Covid-19.esensi Pancasila pada sila 2 (dua) kemanusiaan yang adil dan beradab di saat ini Pandemi Covid-19 empati dan tanggung jawab kemanusiaan benar - benar diuji membentuk satu kesatuan bahwa kita tidak hidup sendiri dan berkewajiban untuk saling menjaga agar wabah tidak menyebar lagi, disiplin protokol kesehatan menjadi tanggung jawab kolektif kolegial.

Implementasi Pancasila sebagai paradigma pembanguan politik manusia dalam masa pandemi sila keesmpat menjadikan kebijkan pemimpin dan elit politik dibutuhkan untuk menghasilkan kebijakan negara yang benar - benar berorientasi pada keputusan bersama rakyat dalam menangani pandemi Covid-19 yang dampaknya pada keberlangsungan kehidupan aman dan sehat. dan paling tidak kita harus mengupayakan 3 hal , pertama masyarakat harus membangun inisiatif perlindungan menyatu secara mandiri dengan semangat gotong royong yang istilah Ganjar Pranowo (2020) Jogo Tonggo. Kedua dalam menangani Covid-19 masyarakat harus berusaha dan memberi apresiasi baik yang dilakukan oleh siapapun termasuk pemerintah yang memberikan kebijkan yang baik. ketiga , rakayat dan masyarakat harus mengkosulidasikan diri dengan kokoh supaya kepentingan public dapat lebih tetcermin dalam rangka memutus mata rantai pandemi.

Implementasi Pancasila sebagai paradigma pembangunan petahanan dan keamanan dalam masa pandemi Covid-19. Pertahanan semesta harus terbangun dan terbina sehingga seluruh komponen nasional untuk dilibatkan baik pemerintah melalui gugus Covid, TNI, POLRI dan seluruh stakeholder yang ada untuk menanggulangi wabah tersebut yang sudah menjadi program pemerintah yaitu $3 \mathrm{M}$ ( Memakai masker, Mencuci tangan, dan Menjaga jarak ) sembari menunggu giliran vaksin sampai ke masyarakat.

\section{DAFTAR PUSTAKA}

Agus Wijaya, 2001, Filsafat Pancasila Sebagai Paradigma Bidang Hankam, Ditjen Dikti , Bandung,

Astrid Susanto Sunarto, 2000, Masyarakat Indonesia Memasuki Abad Ke Dua Puluh Satu, Dirjen Dikti, Jakarta.

Bonna, Charezub, 2020, Hofwarelecture And Reaceach Universitas Indonesia, Jakarta.

Budiono, 2012, Pendidikan Pancasila untuk perguruangi Tingi, Alfabeta, Bandung

BPKD. Banjarkab.go.id/idek.php. 2017, Diakses tanggal 19 Februari 2021.

Elly M. Setiadi, 2005, Panduan Pendidikan Pancasila Untuk Perguruan Tinggi, Gramedia Pustaka Utama, Jakarta

Ganjar Pranowo, 2020, SUARA MERDEKA.com, diakses tanggal 24 Februari 2021.

Heri Hardiawanto dkk, 2019, Spriritualisme Pancasila,Prenadamedia, Jakarta.

https;//bit.ly/3g80pkA IDO 
Majalah Ilmiah Gema Maritim, e-issn: 2656-629x,

Vol. 23, No. 1, Maret 2021, pp. 20-25

Kompas,.com.21/12/2020, diakses tanggal 19 Februari 2021.

Nunuk Suryanti, 2020, Implemantasi Nilai Pancasila Pada Pasca Pandemi. LPPMP UNS, Surakarta.,

Paristyanti Nawandani, 2016, Pendidikan

Pancasila Untuk Perguruan Tinggi,
Direktorat Pendidikan Tinggi, Jakarta

Rohani Ahmad, 2019, Pedoman pengajaran Pendidikan Kewarganegaraan, Depdikbud, Jakarta. 